\title{
Comparative Analysis of Global Media Interview Techniques
}

\author{
Edafejirhaye, I. Vincent \\ Dept of Mass Com, Adeleke University, Ede \\ Adebola, O. Igbekele \\ Dept. of Mass Communication, Adeleke University, Ede \\ Akintayo, O. Atinuke \\ Dept. of Mass Communication,Adeleke University, Ede
}

\begin{abstract}
An engaging interview is essentially a good conversation. Good journalism is dependent on a conversation and participation. At the heart of this issue is the interview. Different types of interviews call for different styles, techniques and different starting points. Thus, this paper focused on comparative analysis of interview techniques employed by foreign and local journalists. With particular focus on interview programmes anchored by Stephen Sackure of BBC, Christiane Amanpour of CNN , Modele Sarafa-Yusuf of Channels, Oluwayomi Osuntokun of EKTV and Michael Malomon of Adaba 88.9 FM, France 24, NTA, TVC and SilverBird televisions. The findings shown that some interviewers are yet to fully comply with global acceptable norms of Media interview. Also, local and national journalists still have some inferiority complexity and kind of fear to ask certain questions from the interviewees even if they knew that question will improve the quality of the interview process. But, foreign journalists are very bold, confident and speak at a realize mood, but very frank with issues at stake. The paper suggests that all media houses retrain their anchor men and women to adopt the acceptable global standard. Also that the local journalists should watch foreign interview programmes on $\mathrm{CNN}$, $\mathrm{BBC}$ and AL JAZEERA. And persons interested in interviewing should seek quality training and observe experienced interviewers whenever possible; then get more experience.
\end{abstract}

Keywords: Media interview, interview technique, Attitudes, Interviewer, interviewee, foreign journalists, and local journalists.

DOI: $10.7176 / \mathrm{NMMC} / 84-03$

Publication date:October $31^{\text {st }} 2019$

\subsection{Introduction}

Interview is one the most common activities reporters all over the world carry out in line of duty as a primary source for fresh information and story balancing. It is also a tool used to beef up the facts journalists have, clarification of issues to make reports more credible. When interviews are systematically employed they go a long way in creating a new dimension to news story. It is an instrument in the hand of media professional with which they unravel hidden facts about personal experiences, organizational behavior, social events and natural disasters. Interview is a way of eliciting information from the interviewee. Different types of interview call for different styles, techniques and different starting points (Asekun, 2018).

Nwanbueze, ( 2011) defines interview as a fact-finding encounter between a reporter (interviewer) and another person referred to as the interviewee that involve asking of questions to elicit information on some issues or subjects. It is a process of asking questions to create, build up or develop a news story which could be aired live in television, radio or publish in print media. The purpose of interview could be to inform and educate media audiences on specific issues. Ufuophu-Biri, (2006) sees interview as a meeting between interviewer and interviewee with aim of eliciting responses from the interviewee. This meeting could be in the street, motor park, scene of accident, place of social gathering or in media studio. Folarin, (1998) defines interview as the act of meeting people face to face or using telephone to find out and write a report about an issue, institution or personality.

According to Reid \& Associates, (2001), the interviewee should do most (75\%) of the talking during the conversations. If, during the interview it was found that the interviewee has lied, the interviewer should generally not confront the interviewer (Grimald, 2005). In his own view, Nwodu, (2006) argues that, in most cases it is best to challenge a lie during a follow-up interview or once the interviewer has transitioned into an interrogation. An interrogation is the process by which suspects are questioned in regards to their involvement in the activity that gave rise to the investigation

\subsection{Theoretical Overview}

This paper is hitched on schema theory. Concept of schema theory, one of the cognitive learning theories, was first introduced in 1932 through the work of British psychologist Sir Frederic Bartlett (some suggest it was first 
introduced in 1926 by Jean Piaget) and was further developed mostly in 1970s by American educational psychologist Richard Anderson. Schema theory describes how knowledge is acquired, processed and organized. The starting assumption of this theory is that "...every act of comprehension involves one's knowledge of the world". According to this theory, knowledge is a network of mental frames or cognitive constructs called schema (schemata). Schemata organize knowledge stored in the long-term memory (Dixon, 2006).

The term schema is nowadays often used even outside cognitive psychology and refers to a mental framework humans use to represent and organize remembered information. Schemata present our personal simplified view over reality derived from our experience and prior knowledge, they enable us to recall, modify our behaviour, concentrate attention on key information, or try to predict most likely outcomes of events. According to David Rumelhart cited in kmikulic,( 2013).

Schemata can represent knowledge at all levels - from ideologies and cultural truths to knowledge about the meaning of a particular word, to knowledge about what patterns of excitations are associated with what letters of the alphabet. We have schemata to represent all levels of our experience, at all levels of abstraction. Finally, our schemata are our knowledge. All of our generic knowledge is embedded in schemata.

Axelrod's schema theory suggests that a message is sent and then received by the audience, the audience evaluates this message based on information currently available to the audience e.g. past experience, redundancy, and relationship to currently understood "truths". This application of audience knowledge compares what the audience perceives to what the audience knows to be true of the message. According to Gavin, (2010) "this theory is one of many that explains and helps us interpret messages sent by the media". The theory was originally applied to messages sent by news media but its application has been extended to cover various interpretations of messages which can extend so far as stereotype research as well as agenda setting during interview programmers.

Schemas are not necessarily misinterpretations of information but a tool we use to perceive the world and understand information flow during intense conversation. At its core schema theory uses the concept of a schema (plural: schemata) to understand how people think, analyze, and act on the information that is presented to them during interview. The theory states that all knowledge/data is organized into units. Each unit is a schema. Within each schema information is stored - this information can pertain to anything. This however, suggests how an interviewer can use schema cognitive ability to elicit needed information from the interviewee.

In our mind a schema is a generalized concept or system for understanding pieces of the world we encounter. The information within your schemata can represent various pluralities of data - for example: events, sequences of events, actions, sequences of action, objects, the relationships they have with other objects, and situational knowledge.

In a schemata analysis, Gavin, (2010) gave a vivid example of Schema theory thus;

A simple example is to think of your schema for a car. Within that schema you most likely have knowledge about cars in general (need gas, have four wheels, you can drive them, etc.) and probably information about specific cars like a Mercedes (expensive, usually silver, Santa delivers them at Christmas) or Fords (from Detroit, American-made, probably a truck).You may also think of cars within a larger context your life - you use one to get to work or class, you have a specific one, you probably want a better one, you got hit by one last year. All these pieces of information come together to form your schema for a car. Every time you learn something new - self driving cars, a new Jeep Renegade, etc. You update your schema of a car.

Schemata can categorize knowledge at all levels - ideologies, cultural truths, knowledge about the meaning of a words, and even stereotypes. We have schemata for all levels of our lives and experience, to all levels of possible abstraction. This theory tends to explains that all journalist's general knowledge about topic under discussions is embedded in a specific schema in their minds. That is our minds reference our schemata all day, every day - they're mental shortcuts we use to understand the world.

The schema foreign journalists have in compares with their counterparts in national and local media is higher therefore, they will perform better than the national and local journalist during interview programmers. Schemata are the cornerstones for our knowledge and decisions, without them quick thinking in interview schedule wouldn't be possible. On this note let us examine various types of media interview.

\subsection{Types of Media Interview}

Hiliard, (2008 p. 267) identifies three major media interviews. They are opinion, information and personality interviews.

\section{Opinion Interview}

According to him, the opinion interview is any interview that concentrates on the beliefs or opinion of an individual. In this type of interview, the prospective interviewee is informed to prepare for it before the programme takes place. Interviewer could also go into the street to garner public opinion about the political 
situation in the country.

Information Interview

The informative interview is usually the public service type of interview meant to give information to the public. In the same vein, Ufuophu-Biri, (2006) describe this type of interview as on the spot interview. According to him, this type is conducted at the scene of an event to serve as a kind of background to the news story. For instance, a reporter may decide to interview the eyewitness account of an automobile accident right on the very spot of the accident. A reporter could also corner organizer of conference or other social gatherings and interview him to generate more information for the public.

Personality Interview

Hiliard, (2008 P. 268) sees personality interview as human interest or feature story which involve experts or professionals interviewee. Ufuophu-Biri (2006) calls this type of interview specialized interview targeted at experts and professionals in order to get their views or input on a current issues. Reporters interview experts on relevant field such as security, economy, politics, foreign affairs, energy, crime, law, custom and many other areas.

Other types of media interviews are forum and panel interviews.

\section{Forum Interview}

Forum interview according to ( Nwanbueze,2005; Ufuophu-Biri, 2006) is the type of interview common at press conferences/press briefing where there are more interviewers than interviewees. Here several interviewers ask questions one after the other and the interviewee responds. The interview may be based on a particular subject or wide range of issues.

\section{Panel Interview}

This type the interviewer may be one and interviewees may be two or more. Each interviewee responds to questions turn by turn. The interview is usually based on topical issue that is relevance to the public. Examples of this interview are the NTA Tuesday live Anchor by Cyril Stober, BBC hardtalk anchor by Stephen Sackur, $\mathrm{CNN}$ talk it back anchor by Christiane Amanpour and others.

\subsection{Global Media Interview Techniques Preparation before the Interview:}

Okoh \& Ogbodu, (1995) stress some points on how interviewer ought to prepare before the interview takes place. Here are some of their points:

The interviewer should know the purpose of the interview. Is it to inform or educate the audience? Is it to create political, economic or social awareness? The interviewer must as a matter of responsibility maintain the focus. The interviewer should prepare two or three essential points that he wants to get across during the interview. He should support his points with facts or anecdotes from your experiences. There is no substitute for preparation. The interviewer should study his subject and ask his friends, family, and colleagues to conduct mock interviews as practice. The interviewer must consider his interview as an "enlarged conversation" and speak as naturally as you would to another person.

\section{During the Interview:}

Before you begin to speak (Hilliard, 2008; Onabajo, 1999; Nwanbueze, 2011; Weiten, 2008) strongly advise interviewer to establish rapport with the interviewee by:

1. Smiling at the interviewee to create welcoming atmosphere.

2. Using vocal variety. Let your voice and your delivery reflect the full spectrum of emotions and points of emphasis.

3. Using gestures that complement the expression of your ideas. Avoid distraction and meaningless movements.

4. Maintaining eye contact throughout the interview and keep a friendly face.

5. Communicating with visible enthusiasm and involvement in your subject.

\section{Getting Your Point Across:}

Nsikan-Abasi,(2005) in agreement with Cohen, (2009) see the interviewers working in media organizations as public relations officers whose duty in television and radio programmes such as media interview is to build, maintain and sustain image of the interviewees, the interviewer himself and his media organization. They therefore ; put forward the following behavioural suggestions during interview section:

The interviewer must be assertive - in a pleasant way - so that the conversation centers on subjects he wants to talk about. One way to do this is to respond to a narrow question with a very broad answer that encompasses the facts or opinions you need to get across.

The interviewer should listen carefully to the question. If he considers the question difficult, pause before he answers to give himself time to formulate a response. If you don't understand a question, ask that it should be repeated.

Be careful not to repeat an interviewer's words, unless they reinforce what you wish to say. If an interviewer 
poses false premises in asking a question, correct him/her firmly but politely.

Use your time to set the record straight or present facts. You might say, "This is a common misperception. Deflect questions you do not wish to answer by introducing something else of interest. In this way, you may redirect the interview to the subject you wish to convey.

Don't try to answer hypothetical questions; they tend to obscure your true position. Turn the tables by clearly stating your general position and then offering your own example.

Use short words and simple, declarative sentences. Avoid scientific terminology. Be descriptive, using images that the listener can picture.

Use analogies whenever possible to simplify and dramatize your main points. Where appropriate, relate personal experiences or illustrations of your work to support your statements. Telling something about yourself will "humanize" you to the audience.

If you use quotations, keep them short. If you can't recite the quotation verbatim, don't use it.

If you don't know the answers to a question simply say, "I don't know, but I'll find out the answer and get back to you." If you have a legitimate reason for withholding certain information then politely say it's confidential or proprietary.

Use the Inverse Pyramid in structuring responses. Start with a general statement that sums up your position or philosophy succinctly and accurately. In the second part of your answer you should narrow down your response by giving the specifics of why you feel the way you do. This approach is particularly valuable for radio and television. If a producer decides to cut your five minute taped interview down to one minute for the evening news, chances are he/she will use your general statement.

\subsection{Tips for Television and Radio Interview}

Hilliard, (2008); Onabajo, (1999) and Nwanbueze, (2011) in separate writing put in place general rules to guide interviewers and interviewees during interviews section. Here are some of them.

Treat your host and the audience as you would friends. Be friendly, spontaneous, and responsive.

Know the length of your interview before you go on. If you have only brief interviews condense your answers citing your main points quickly. Think in terms of outline rather than exposition.

Before the interview begins, try to learn something about your host's likes, interests, and prejudices. This helps you involve him/her more personally in your conversation.

Don't think of your host as an adversary. With rare exception, he/she will want you to look good so that he/she looks good. Relax, but stay mentally alert.

Most interview programs will have the host or someone from the production staff "pre-interview" you before you go on, if only for a minute. This will establish what is expected of you, the direction the interviewer intends to take, and how much time you will be allotted. If no one goes over your presentation with you, ask if some time could be made available for this purpose.

It is perfectly all right to consult notes during the course of the radio interview. Put them on index cards sheets of paper rustled next to a microphone sound like a barn fire.

Radio interviews can sometimes be casual to the point of the host forgetting to tell you that you are on the air. As soon as you are seated in front of a microphone, ask when the interview will actually begin.

On television, look your interviewer in the eye and call him/her by his/her first name, unless he/she is much older than you. Ignore the technicians on the set and look at the camera only when you want to drive home a special point directly to the viewing audience.

Defensive body language like wringing hands, folding arms across the chest, clenching fists, or narrowing eyes should be avoided. Gesture naturally, and vary your gestures.

Men are advised to wear calf-length hose so that no bare skin shows when legs are crossed. If possible, men with heavy beards should shave just before air time, since stubble is exaggerated on camera.

Women should wear solid colors (avoid white or black) and keep jewelry to a minimum. Avoid jewelry that reflects light or makes noise.

\section{Responding to Audience Questions}

Many radio and television programs use question and answer call-in formats to encourage audience participation. You will find most of the questions that arise are easy to handle.

Calls are screened by the station to eliminate those that may be abusive or irrational, and the host is likely to be helpful if you get a difficult caller.

You should be able to anticipate many queries. Write out expected questions and your answers before the time of your interview. Since the call-in segment usually follows an interview, it's good to introduce some new information in your responses.

On television, body language is important. Don't cling to furniture or cross your arms tightly - you want to convey an air of openness and accessibility. Even if a question is irrelevant, appear to be concerned about what 
the person has to say. If the same question is asked more than once, patiently answer it again.

When someone asks several questions at once, you are free to choose the one you'd like to answer and ignore the others. If the question is one you'd rather not answer directly, use it to lead into a point you do want to make.

If you don't know the answer to a question, say so. Cite a possible source of the information or offer to get the information for the questioner (Cohen,2009; Nwanbueze, 2011 ; Ufuophu-Biri, 2006).

\subsection{Tips for Newspaper and Magazine Interviews}

Never speak off the record; assume that everything you say will be reported, whether it's before, during, or after an interview ( Nwanbueze, 2011; Onabajo, 1999). Therefore keep records in electronics and books. Make sure that what you tell the reporter is what you want to see in print. If you are unhappy with the way you have phrased something, stop and rephrase or clarify your original statement. If you realize after the interview that you misstate a fact or phrase something poorly, call the reporter to correct the error. A newspaper reporter will not allow you to review copy before it is printed. You can, however, extend your influence over the article by inviting the reporter to call you for more information or clarification.

\subsection{Example of a Print Media Interview} Special Interview with Senator Emmanuel Aguariavwodo Profile of Interviewee

Sen. Emmanuel Edesiri Aguariavwodo was senator of the Federal Republic of Nigeria in 2013 to 2015. He is visionary and transformational leader. The distinguished senator is a pace setter and a role model for our generation. He is results-oriented with over thirty years experience in policy and strategy development, financial budgets, economics, journalism; well qualified with expertise in private and public sector policy formulation, strategic planning and relationship management; extensive involvement in political leadership, legislation and economic stimulation. He also had a proven record of leadership with outstanding management and team building abilities; skilled in team motivation, development, coaching and mentoring; strong interpersonal, networking and negotiation skills; sound communication skills: written, verbal \& presentations; trustworthy with very strong ethics.

He was born on December 8; 1957. Senator Emmanuel Edesiri Aguariavwodo, a dynamic and purposeful Nigerian comes from a humble family background in Okpare-Olomu, Ughelli South local Government area of Delta state.

He attended St. Joseph Roman Catholic Mission Primary School, Okpare between 1963 and 1968; Ibru College Agbarha-Otor and St. Gregory's College, Ikoyi, Lagos, where he obtained his West Africa school certificate and Advance Level certificate. Emma as he is foundly called by friends proceeded to the University of Benin where he graduated with a B.SC. (Honours) in Economics in 1983. Recently, in the year 2000 to be precise, he attended the famous Harvard University's John F. Kennedy School of Government, Harvard Institutes for international development in Cambridge, Massachusetts, U.S.A where he obtained an Advanced Certificate with Distinction in the program on Budgeting and Financial Management in the public Sector. In April 2014 he also attended the Johns Hopkins University's' School of Advanced International Studies in Washington DC USA for a course in Executive-Legislative Relations and performance.

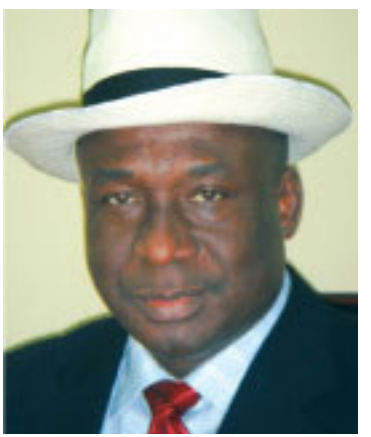

Senator Emmanuel Edesiri Aguariavwodo

Former managing director of NDDC.

Source: Edafejirhaye (2018)

Sir you are welcomed to this interview. Can you give us some information about your political career?

Before I was elected as a senator of the Federal Republic of Nigeria, I was a one time member of Federal House of Representatives and former Managing Director of Niger Delta Development Commission (NDDC) were I 
distinguished myself in exceptional service and commitment to elevating the standard of life of my people and the nation at large

During my tenure in the house, I did not disappoint Deltans. I pioneered legislations that revolutionized the participation of indigenous companies in oil and gas sector of the Nigeria economy aptly titled 'Operation procedure (regulation) of the petroleum company Act 2001". This bill sought to make it mandatory for the oil companies to look inward to Nigeria and Nigerians for sourcing of their raw materials and equipment. This has inevitably evolved to what is known today in the oil and gas sector as the local content which is now a full fledge Commission overseen by a Management Board.

What did you do to make life better for Niger Delta people as one time managing director of Niger Delta Development Commission?

I participated actively in the activities that culminated into the enactment of the law setting up the Niger Delta Development Commission (NDDC). I was among the selected committee that toured the Niger delta region to get the input of the various stakeholders into the law that is to bring succour to the impoverished people of the region, when implemented. Like a gold fish that has no hiding place, I, Emmanuel Edesiri Aguariavwodo was in November 2003 appointed by President Olusegun Obasanjo as the Managing Director/Chief Executive Officer of Niger Delta Development Commission. Since then I have shown my dynamism and leadership qualities in steering the NDDC to greater heights. Some of my achievements at the NDDC includes:

Design of Action Plan for transformation at the NDDC. An interim action plan involving physical infrastructural development of the Niger delta and capacity building programmes was embarked upon pending completion of the regional master plan. As at December 2006 total infrastructural projects awarded by the commission from inception stood at 2,171. While in the period of my stewardship, 1,459 infrastructural development projects were awarded out of which 163 were completed, 1,027 are ongoing and 9 stalled. Of the completed projects, 125 were completed and commissionable. In addition, 276 projects out of 712 awarded by the previous regime were completed and commissioned during this period as at 2018 .

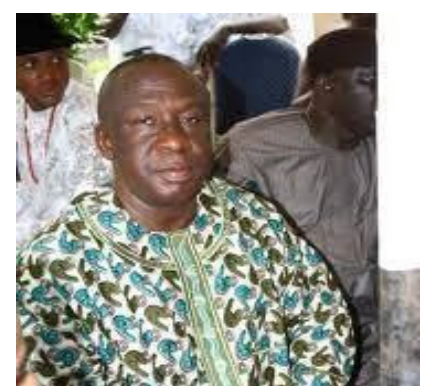

Senator Aguariavwodo in UPU meeting.

Source: Edafejirhaye (2018)

What will people of Niger Delta, particularly the Urhobos remember you for?

The people will remember me for the massive infrastructural development in the Niger Delta region. When I was at the NDDC, the profile of the organisation rose due to the very concrete achievements in roads and bridges, school buildings, health centres, canalisation and shores protection, water and electrification projects that have been delivered by the commission in the Niger Delta Region. There were also programmes on youth/women empowerment and development in skill acquisition, sport development and job creation. Under my watch, the Niger Delta Regional Development Master Plan was completed and implementation commenced in earnest with the inauguration of the Partners for Sustainable Development Forum [PSD] which is comprised of the NDDC, the 9- state Governments, the oil companies and all other stakeholders and development providers in the region. This is with a view to mobilizing every segment of the development chain to a common development agenda for synergy and optimization in resource utilization.

To enhance the capacity of civil society to engage in development activities, with a view to complementing the efforts of Government. I in conjunction with men of like minds established the Peoples Cooperative Society (PCS), which has been in the vanguard of engaging in micro financing among its members spread across my home state - Delta. The PCS is undergoing current restructuring to make it one of the leading Non-Governmental Organizations (NGO's) in the Niger Delta.

In view of what you achieved in NDDC, were your effort appreciated in any way?

In recognition of my outstanding accomplishment, various organisations have continued to honour me with various awards.

Amongst these awards are: 
The University of Benin Alumni Award for excellence,

The Rotary District 9130 Community Service Award

AIT Award for Excellence in the Development of the Niger Delta.

Award for Leadership and Excellence by the Nigeria Advancement Award

Certificate of Honor by the Nigeria Union of Journalist

The NAPIMS Award of 2001. Others are still coming.

\section{What were you doing for a living before you step into politics?}

I ventured into journalism because of my innate interest in public affairs and the public good. In my career at The Guardian Newspaper, I wrote prolifically in The Guardian, The Guardian Express and Lagos life. In fact, I kept a column with Guardian Express for a number of years even after I left active journalism. In 2000, during the 45th anniversary celebration of the Nigerian Union of Journalist (NUJ), I was presented a certificate of Honour by the union in recognition of my contribution to journalism profession and for being a good ambassador of the union. Most of the published column materials are now in a book form appropriately titled 'A NATION OF MY DREAM'. I also author a collection of poems titled 'OUR LOVE, OUR FREEDOM'. I was also a very active member of the Nigerian Economic Summit Group where I presented a number of position papers on the economy.

What is your opinion about 2019 general election, Will PDP reclaim the presidency?

There is no doubt that the election will surely hold and PDP may have landslide victory over APC led administration. The incident of herdsmen killing and other events in Nigeria show that President Buhari will failed woefully and no Nigeria citizen may likely vote for failure and hunger.

As a senator of the Federal Republic of Nigeria, which other ways have you touched life of people?

I am the first Nigerian and Deltan who donated relief materials worth hundreds of thousands of naira to assist the victims of the Warri crisis through the Delta state Government at Asaba on April 29; 1997. I also financed and organized the well acclaimed WARRI PEACE AND CHARITY CONCERT on September 27; 2015 at the cricket pitch of Tafawa Balewa Square, Lagos in collaboration with DAAR Communications Ltd, Lagos. This Effort was to preach the gospel of peace and also to assist the victims of Warri crisis. This clearly portrays my firm belief in good neighborliness and the need for Deltans to continue to live in peace with one another.

I, along with other like-minded people from all the major ethnic groups in Delta State in 1993 formed the famous DELTA FRONT. This body amongst other things was responsible for highlighting the fact that Delta State was indeed the highest oil producing state in Nigeria at that time and that the then revenue allocation formula needed to recognize this fact in distributing revenue amongst the states of the federation. Delta Front made two publications, the first was on October 22, 1993 while the second was on November 16, 1993 both of them in The Guardian Newspaper. Based on these activities and publications by Delta Front, the Federal Government eventually corrected the anomaly and Delta State correctly took its place as the number one oil producing state in the country and all the associated benefits accruable thereto until the 1999 constitution came into operations.

Thank you very much for your time. We shall get back to you some other time.

\subsection{Media Interview Techniques: Interviewers' Right and Wrong Attitudes}

This section analyses various media interview techniques from different region of the world. CNN TV represents America continent, France 24 TV \& BBC TV represents Europe while in Africa NTA TV, Channel TV, TVC TV and SilverBird TV were picked. The analysis of right and wrong attitudes of interviewers and interviewees during interview are presented in table 1 . The global acceptable attitudes during interview are presented in the "right attitudes" column while the global unacceptable attitudes are in the "wrong attitude" column. Media anchor men and women should adopt the positive attitudes in line with what Nsikan-Abasi, (2005), Hilliard, (2008), Onabanjo, (1999) and Cohen, (2009) observed. For they see the interviewers working in media organizations as public relations officers whose duty in television and radio programmes such as media interview is to build, maintain and sustain image of the interviewees, the interviewer himself and his media organization. 


\begin{tabular}{|c|c|c|c|}
\hline Media Houses/ Topic & $\begin{array}{ll}\text { Name of } \\
\text { Interviewer }\end{array}$ & Right Attitudes & Wrong Attitudes \\
\hline $\begin{array}{l}\text { CNN- Talk it back } \\
\text { May 12; } 2018 \\
\text { Interviewee: President M. } \\
\text { Buhari of Nigeria. } \\
\text { Topic: Anti-Corruption } \\
\text { crusade }\end{array}$ & $\begin{array}{l}\text { Christiane } \\
\text { Amanpour }\end{array}$ & $\begin{array}{l}\text { 1.she is friendly to interviewee. } \\
2 \text { She is always focus on the } \\
\text { topic. } \\
3 \text { She gives enough time for } \\
\text { interviewee to express points. }\end{array}$ & $\begin{array}{l}\text { Time for the interview } \\
\text { is too short. }\end{array}$ \\
\hline $\begin{array}{l}\text { BBC- Hardtalk } \\
\text { March } 2018 \\
\text { Interviewee: Mahira Khan. } \\
\text { Topic:Pakistan Movie } \\
\text { Industry. }\end{array}$ & Stephen Sackur & $\begin{array}{l}\text { 1.He is focus on the topic. } \\
2 \mathrm{He} \text { is bold \&friendly to } \\
\text { interviewee } \\
3 \text { Patient with interviewee }\end{array}$ & None \\
\hline $\begin{array}{l}\text { NTA- Tuesday Live- Panel } \\
\text { Interview } \\
\text { April 4;2018 } \\
\text { Interviewees: } \\
1 \text { Sen. Magnus Abe } \\
2 \text { Lawan Ahmad } \\
3 \text { Nura Khalil. } \\
\text { Topic: As Buhari Declares: } \\
\text { What next? }\end{array}$ & Cyril Stober & $\begin{array}{l}\text { 1 There is relax scene. } \\
\text { 2.Rapport was established with } \\
\text { friendly introduction of } \\
\text { interviewees. } \\
3 \text { Phone-in was allowed } \\
\text { 4Interviewees were given enough } \\
\text { time to express themselves. } \\
5 \text { Interviewer remained neutral to } \\
\text { the topic. }\end{array}$ & $\begin{array}{l}\text { Some of the callers } \\
\text { who phone in were not } \\
\text { given enough time to } \\
\text { express themselves. }\end{array}$ \\
\hline $\begin{array}{l}\text { Channel TV. April;2018 } \\
\text { Interviewee:Gov. Ayo Fayose } \\
\text { of Ekiti state, Nigeria. } \\
\text { Topic: PDP Quest to retain } \\
\text { dominance }\end{array}$ & Mr. Seun O. & Good scene & $\begin{array}{l}1 \text { interviewer too harsh } \\
\text { on interviewee. } \\
2 \text { interviewee was not } \\
\text { given enough time to } \\
\text { express himself. } \\
3 \text { interviewer tries to } \\
\text { content interviewee's } \\
\text { Points. }\end{array}$ \\
\hline $\begin{array}{l}\text { TVC TV -Big Talk } \\
\text { April, } 2018 \\
\text { Interviewee:Gov. Ayo Fayose } \\
\text { of Ekiti state, Nigeria. } \\
\text { Topic: Big talk with Gov. } \\
\text { Ayo Fayose }\end{array}$ & Richy White & $\begin{array}{l}\text { 1.He is friendly \& focused. } \\
2 \text { Very bold \& strategically tactful } \\
\text { to unravel more questions from } \\
\text { interviewee's answers } \\
\text { 3. He is relax and respectful. }\end{array}$ & $\begin{array}{l}\text { The interviewee made } \\
\text { too many political } \\
\text { spurious statements to } \\
\text { divert attention of the } \\
\text { anchor man. }\end{array}$ \\
\hline $\begin{array}{l}\text { SilverBird TV- Head to Head. } \\
\text { May 9; } 2018 \\
\text { Interviewee: Gov. Ambode of } \\
\text { Lagos state, Nigeria. } \\
\text { Topic: Assessment of } \\
\text { Ambode's performance. }\end{array}$ & $\begin{array}{l}\text { Kehinde } \\
\text { Bamigbetan }\end{array}$ & $\begin{array}{l}1 \text { There is good interactive } \\
\text { atmosphere. } \\
2 \text { Relax scene but many } \\
\text { interruption from the anchor man }\end{array}$ & $\begin{array}{l}1 \text { no enough time for } \\
\text { interviewee express } \\
\text { points. } \\
2 \text { Too many cut in by } \\
\text { anchor man } \\
\text { 3. Interviewer arguing } \\
\text { with interviewee. }\end{array}$ \\
\hline $\begin{array}{l}\text { France } 24 \text { TV- The Interview. } \\
\text { May 30;2018. } \\
\text { Interviewee: F.A. Touadera, } \\
\text { President of Central African } \\
\text { Republic. }\end{array}$ & $\begin{array}{l}\text { Anthony } \\
\text { Richard }\end{array}$ & $\begin{array}{l}\text { 1.relax scene } \\
\text { 2.Focus on the topic } \\
\text { 3.Enough time for interviewee to } \\
\text { express self. } \\
\text { 4.Bold \& respectful }\end{array}$ & None \\
\hline
\end{tabular}

Table 1. Global Media Interview Acceptable Attitudes Source: Youtube and Edafejirhaye (2018)

From the table above, this paper observes that right attitudes should be adopted by media interviewers in the global media houses. Therefore lessons observed from CNN, BBC, AL JAZEERA.,NTA, TVC, Channel and SilverBird televisions indicated that the foreign journalists used well structured interview techniques to elicit needed information than local journalists in an interview programmes. Also, foreign journalists are very bold, confident and speak at a realize mood, but very frank with issues at stake. They are very confident when interviewing and take charge of the whole interviewing process. Sometime, they challenge interviewee if a statement demands it, or if they felt it will improve the quality of the conversation. 


\subsection{Seating Arrangement in the Foreign Stations Interview}

The seating arrangement during interviewing programmes in the foreign stations, especially in $\mathrm{BBC}$ and $\mathrm{CNN}$ seems to be very crucial. They consider interviewing in a more lounge-style atmosphere, with soft seating, rather than a small, cell-like meeting room with a table and two chairs, as we have it in most of the local stations in Nigeria. For a more confrontational style, for example," the hard talk" interview conversation between Stephen Sackure BBC and former U.S. White House Communication Director, Anthony Scaramucci, the choice of the set up arrangement appears to be confrontational in a traditional set up without a table between the interviewer and the interviewee. Ultimately, the target when conducting interviewing in most of these foreign stations was to make sure the atmosphere and environment helps the interviewee to communicate freely and comfortably. Although, similar set up is being done in most of the local stations, but it leaves much for improvement.

According to Boyed (1997) cited in Asemah, ( 2011) "An important component of any interviews is keeping the interviewees calm and at ease - and ready to show their true selves. And setting is an important factor in establishing this rapport." These guidelines for setting up an interview room will help the interviewer get the most out of his interviews - and interviewee. Once a good setting had been chosen and an ideal environment for the interview, the interviewer can fine-tune the interview to establish open and honest lines of communication as quickly as possible. In the foreign media stations, a careful study of the settings shows that they want to keep their interview space free from interference except in a multi- setting interview programmes where the audience were invited as spectators, this includes removing interruptions from inside the interview room, but also covering windows with views to the exterior that might be a tempting distraction.

\subsection{Seating Arrangement in the National Media Interview}

As earlier noted in the foreign media interview programmes, most of the national media stations also remove any possible interruptions from their interview programmes. They will want to keep the interview space free from interference. A typical example can be seen when Modele Sarafa- Yusuf (Channel TV) was interviewing former president Chief Olusegun Obasanjo in an interview programme titled "View from the Top ".The chairs were properly arrange to establish rapport (without violating his personal space), the chairs were set between 1.2 to 1.5 metres apart. In cases where there are two or more interviewers, they fan their chairs out at equal distances from the candidate's, but as close to each other as possible, to make it easy for them to maintain eye contact. This practice support the view of Gillham, (2005) and Dempsey, (2003) which argue that " establish rapport (without violating someone's personal space), set the chairs 1.2 to 1.5 metres apart. If there are two or more interviewers, fan their chairs out at equal distances from the interviewees, but as close to each other as possible, to make it easy for them to maintain eye contact". Compare to BBC and CNN interview sittings, most national media interview programmes sitting seems to be too-small which make most interviewees feel claustrophobic.

\subsection{Seating Arrangement in the Local Stations Interview}

Compare to both foreign and national seating arrangement, local media interview setting appears to be adversarial in nature. As innocent as it may seem, seating can determine the entire atmosphere of an interview. Round tables and identical chairs create a positive feeling, but if the interviewer sits in an executive armchair and interviewee sits on a regular one, this establishes a distance. It also increases the hierarchic difference between the interviewer and the interviewee. An example of this could be seen in an interview between Oluwayomi Osuntokun (EKTV) and Peter Ayodele Fayose the Governor of Ekiti State, in an interview programme titled "Meet your Governor", the set-up seating arrangement was triangular where the anchor man was seating at right side, the Governor in an executive armchair in the middle and other interviewers at the left side. The anchor man seems not to be comfortable as he will need to twist and strain his neck intermittently to ask his questions from the Governor. This type of seating arrangement is common with most local media stations in an interview programmes. According to Calliope, (2016).Collaborative sitting is sitting next to each other at an angle of about $45^{\circ}$ to create a collaborative feeling. The interviewer wants you to be open and relaxed during the interview. While adversarial sitting on the opposite side of the interviewer's desk, might give a feeling of inferiority, especially if the desk is not cleared and the computer is still switched on.

\subsection{Interview's Style in Foreign Media Stations}

The foreign journalists demonstrate high approachable styles, fact-finding interviews and on-air encounters with ordinary people in extraordinary circumstances. They will create extraordinary circumstances, keeping the audience engaged from which the interviewee will not be allowed to slide away. Typical scenario of this could be seen when Christiane Amanpour CNN was interviewing the author of Americana, Chimamanda Ngozi, . Amanpour used different approach to challenge evasions and unfounded propaganda without making the whole exercise a shouting match.

On the other hand, the journalists in local and national media stations still exercise some certain fear in 
stopping the interviewee if they are overlapping one of their other questions or sliding away from the original questions raised.

A typical example can be seen when Modele Sarafa- Yusuf (Channel TV) was interviewing former president Chief Olusegun Obasanjo in an interview programme titled "View from the Top ". The former president was totally out of context, yet the interviewer was not too confident enough to make a mental reminder that he has not answered the other questions raised.

\section{Non Verbal Cue Technique}

The foreign journalists maintain a very high level of body language and gesticulation as interviewing techniques to gain a further sense of context while engaging and conversing with the interviewee (Calliope, 2016). This is very common to Amanpour ( CNN), Stephen Sackure and Peter Allen (BBC). Among the local journalists, there are many emotional and mental stumbling blocks that prohibit them inherently from approaching interviewee with more convincing non-verbal interview techniques.

\section{Sense of Feelings Techniques}

Foreign journalists were very bold compare to our local journalists during interview. These foreign journalists were very sound and analytical in the way and manner they present their questions and expect response from the interviewee. They were not intimidated regardless of the status of the interviewee. But in the local media, the journalist is being intimidated by the politicians. For instance, in the interview programme between Oluwayomi Osuntokun (EKTV) and Peter Ayodele Fayose, the ex-governor of Ekiti State, on the programme "Meet your Governor", the interviewer became spectator and freak out as the Governor spoke at the top of his voice and took charge of the whole interview exercise. Similarly, in the interview programme between Michael Malomo (Adaba 88.9 MHz FM, Akure, ) and Chief Yele Ogundipe, Commissioner of Finance in Ondo state, the interviewer was candidly too apologetic with the following expressions: "with due respect," "please don't be offended I will like to ask" and others.

Also, local and national journalists (except for some few cases) used conversation stoppers, such as doublebarrelled (even tripled-barrelled) questions. "Why did the campus police use pepper spray on student protesters? Did you give the order?" Double-barrelled questions give the interviewees a choice that allows them to avoid the question they want to ignore and choose the less difficult one.

On the contrary, the foreign journalists speak at a realize mood, but very frank with issues at stake. They are very confident when interviewing and take charge of the whole interviewing process. Sometime, they challenge interviewee if a statement demands it, or if they felt it will improve the quality of the conversation. But in the local stations, except in rare cases, the journalists will maintain a low esteem profile and timidity , especially if the interviewee is public office holder for some certain fear.

But the foreign journalists are not ashamed or apologetic for whatever questions they asked. They don't apologize for stopping the interviewee intermittently or for taking their time. Instead, they thank them.

\section{Listening Techniques}

The foreign journalists listen to the answers and do not become preoccupied with the questions. They try to understand and empathize with the interviewee. After that, in contrast to the local interviewers, the foreign interviewers stick to the question and demand an answer. Amanpour, for instance, has very strong listening interview techniques. The foreign journalists look straight into the eyes of the interviewee intently with the sense of what he/ she wants to get from the interview. Conversely, when they are interviewing they try and break questions up so that they can get shorter and more concise answers.

But in the local or national interview programme, journalists are seem to be too preoccupied with the crafted questions to be asked than listening to the interviewee in other to generate further follow -up questions .

\section{Information Flow Techniques.}

This is probably the most important interview skill that was noticed among foreign journalists during interview programme. They mostly used conversations starters such as; "How?" "What?" "Where?" "When?" "Why?" and encourage expansive answers that produce an abundance of information needed to produce a complete and accurate story.

They want to strike a balance between a conversation and getting the communication flowing. As the interviewee was answering their questions, they are thinking about what they'll ask next and why. They work on their information flow.

The way their questions flow seem natural and conversational. Unlike what the local journalist will do, the foreign journalists don't spin their subject off on a completely different topic just because that's the next question on their list. They think about segues and transitions. Thus, the interviewing programme flows conversationally from beginning to the end. 


\subsection{Conclusion}

In conclusion this paper imbibes the opinions of media experts consulted in this work that right attitudes must be observed by media interviewers in the global media houses. Therefore lessons observed from $\mathrm{CNN}, \mathrm{BBC}, \mathrm{AL}$ JAZEERA.,NTA, TVC, Channel and SilverBird televisions indicated that the foreign journalists used well structured interview techniques to elicit needed information than local journalists in an interview programmes. Also, foreign journalists are very bold, confident and speak at a realize mood, but very frank with issues at stake. They are very confident when interviewing and take charge of the whole interviewing process. Sometime, they challenge interviewee if a statement demands it, or if they felt it will improve the quality of the conversation.

But a close scrutiny suggests that local and national journalists still have some inferiority complexity and kind of fear to ask certain questions from the interviewee even if they knew that the question will improve the quality of the interview process. The local journalists are yet to master some basic interview techniques and art of interviewing.

However, Persons interested in interviewing should seek quality training and observe experienced interviewers whenever possible; then get practice, practice and more practice.

The best interview trainers are interviewers. The paper suggests that the local journalists should watch foreign interview programmes on CNN, BBC and AL JAZEERA. However, Media anchor men and women should adopt the positive attitudes in line with what Nsikan-Abasi, (2005),Hilliard, (2008), Onabanjo, (1999) and Cohen, (2009) observed. For they see the interviewers working in media organizations as public relations officers whose duty in television and radio programmes such as media interview is to build, maintain and sustain image of the interviewees, the interviewer himself and his media organization. Thus, all media houses should get their anchor men and women retrain to adopt the acceptable global standard.

\section{Acknowledgement}

I hereby acknowledge Dr. Asekun-Olarinmoye, O. our lecturer on "Media Interview Techniques" and dean of the faculty of business and social sciences in Adeleke University, Ede. I also appreciate my course mates for helping to criticize and boost this work - Mr. Akintunde, Mrs Akintayo, Mrs Molomo T. and Mr. Igbekele, Ademola

\section{References}

Asekun, O. S. (2018). Interview techniques seminar. Ede: Adeleke University \{Course notes\} .

Asermah, E. ( 2011). Principles and practice of mass communication. Jos. Great Future Press.Calliope, A. (2016). Interview seating. Retrieved from www.calliope.be/.../topic BF244816-2C6F-487E-AECC05D3084368E4 A316B3F1 on 27/6/18.

Cohen, W.A (2009). How to Make it Big as a Consultant. New York. AMACOM.

Dixon, T. L. (2006). Schemas as average conceptions: Skin tone, television news exposure, and culpability judgments. Journalism and Mass Communication Quarterly, 83(1), 131-149. (Links to Full Article PDF)

Edafejirhaye V.I (2018). Media Interview Techniques. Seminar paper presented to Dept. of Mass Communication, Adeleke University, Ede Osun State.

Folarin, B. (1998). News Reporting: Hints for the Beginners. Ibadan. Kraft Books Ltd.

Grimald, R. (2005). Back To The Future: Nonunion Coworker Representation In Employer

Gavin, D. (2010) . The brief overview of schema theory. Retrieved from https://masscommtheory.com/theoryoverviews/schema-theory, on 18/4/2018.

Hilliard, R.L. (2008). Writing for Television, Radio, and New Media. Australia. Thompson `Wadsworth.

Kmikulic, L.(2013). learning theories/schema theory.txt • Retrieved from https://www.learningtheories.org/doku.php?id=learning theories:schema theory on 18/4/2018

Nwodu, C. (2006). Journalism practice: news aesthetics, ethics and laws. Enugu. Rhyce Kerex publishers.

Nsikan-Abasi, S.N (2005). Public Relations in Television. in International journal of ' communication \& interdisciplinary journal of studies. Nsukka. UNN Press.

Nwanbueze, C (2011). Magazine and Newspaper Management: An Introductory Text. Owerri. ' TopShelve Publishers.

Nwanbueze, C. (2011). The Art of Investigative Reporting: A practical guide. Enugu. Daisy Press.

Okoh,N.U \& Ogbodu, J.O (1995). A Guide to Announcing and Performance. Ibadan. Caltop ` Publications.

Onabanjo,O (1999). Essentials of Broadcasting Writing and Production. Lagos. Gabi Concept `Ltd.

Ufuophu-Biri, E. (2006). The Art of News Reporting. Ibaban. Ibadan University Press.

Reid, J.E. and Associates (2001, June). Monthly Investigator Tips. Retrieved from http://www.reid.com/educational info/r tips.html on 26/6/18

Weiten, W. (2008). Pychology: Theme and Variation. Australia. Wadsworth Cengage Learning. 